\title{
Perceptions of Intra-Organizational Collaboration and Media Workers' Interests in Media Innovations
}

\author{
Oscar Westlund \\ Department of Journalism, Media and Communication, University of Gothenburg \\ oscar.westlund@jmg.gu.se \\ www.oscarwestlund.com \\ Arne H. Krumsvik \\ Department of Journalism and Media Studies, Oslo and Akershus University College of \\ Applied Sciences \\ arne.krumsvik@hioa.no \\ www.krumsvik.com
}

\begin{abstract}
This article contributes with a unique quantitative study of newspaper executives' perceptions of the interest and collaboration contained within digital media innovation among staff in the editorial, business and IT departments. Two research questions are explored: (1) Do newspaper executives perceive that there is diverging interest in digital media innovation across the editorial, business and IT departments of their organization? (2) Amid digital media innovation, and also in relation to the interest in such activities among departments, do newspaper executives' perceive that the collaboration between members of editorial, business and IT departments has increased? The empirical analysis draws upon two surveys of Norwegian newspaper executives conducted in April 2011 and April 2013. Results show that the various explorations of digital media are not perceived to have fostered increased collaboration between the actors in the three departments. However, there was a significant relationship related to the size of newspapers measured by circulation: larger newspapers had higher scores on intra-organizational collaboration. Media workers involved in
\end{abstract}


production (editorial staff of the newsroom) and sales (business department) are perceived to be significantly less interested in digital innovation work compared to their colleagues in the IT department. Multivariate analysis revealed the technologists perceived interest in change to be a key predictor for perceived change in intra-organizational collaboration. This indicates the important role of the IT department, in relation to the newsroom and the business department, for innovation relating to the production and distribution of news.

\section{Introduction}

The transforming and increasingly challenging mediascape is putting pressure on legacy news media (Anderson, Bell \& Shirky, 2012), and their historically established organizational and institutional arrangements of journalism (Picard, 2014). This, in turn, leads to incentives for legacy news media to innovate in their newsrooms (Pavlik, 2013), as well as organizations as a whole. This article studies the psychology at work in the behavior of legacy news organizations related to digital media innovations, with the adaptive cycle model (Miles and Snow, 2003) as a theoretical framework. Based on two surveys of newspaper executives, perceptions of intra-organizational collaboration and media workers' willingness to change are analyzed. A key finding is the perceived importance of the IT department - rather than the editorial newsroom or the business department - for triggering adaptations to altering conditions for the production and distribution of news. This is likely to have a negative effect on the efficiency of change in newspapers.

Media innovation involves both processes of change and the outcome of distinct efforts toward such change. While interlinked to invention - the processes of developing products and services - innovation mainly connotes the processes of implementation (Storsul and Krumsvik, 2013, p. 14). The concept of media innovation comprises the innovation of media technology as well as media work. Naturally these two dimensions are interlinked and, in continuation, also relate to user and societal innovations (Bruns, 2014). While the field of innovations has been marked as lacking theoretical substance when applied to the media sector (see reviews in Mierjewska \& Hollifield, 2006; Sylvie \& Weiss, 2012; Wirth, 2006), there have been distinct attempts at addressing such voids in recent scholarly debate (see reviews in Bleyen et al. 2014; Dogruel, 2014). To date, relatively few scholars of media innovations, media studies and media management have commanded close attention to the interplay of innovation and organizational dynamics in media firms (exceptions include Baumann, 2013; Bleyen et al. 2014; Nielsen, 2012; Raviola, 2010),

This article focuses on the interest and intra-organizational collaboration of distinct media workers and shapes how media technologies come about. It is thus less concerned with the innovation of media technology per se. The article focuses on media innovation in terms of the salient case of digital media innovation among newspapers. In brief, the press in the Western world is under tremendous pressure. Increasing competition in a digital mediascape - with 
shifting audience and advertiser patterns - have resulted in a diminishing effect of the traditional business model, which is ultimately challenging the future of journalism. Digital media innovation marks an important measure towards attempting to counterbalance these challenges. This article does not study more general and environmental factors per se, but instead how such factors touch base with responses, adaptations and interventions in the form of digital media innovations among legacy news media. More specifically, it investigates managerial perceptions in the intra-organizational context of newspapers. The article focuses on the so-called administrative problem in the adaptive cycle model - involving structure, process and innovation - as theorized by Miles and Snow (2003; cf. Snow, Miles \& Miles, 2005). More specifically, it analyzes survey data on how Norwegian newspaper executives perceive that three distinct professional groups have involved themselves in a series of media innovation projects during 2011 and 2013. Involvement here refers to the newspaper executives' perceptions of the interest and collaboration of digital media innovation in the editorial, business and IT departments within newspaper organizations.

The article is outlined as follows: The next section sets the context for digital media innovation in newspapers. Thereafter we introduce the adaptive cycle model, present the study rationale, discuss method and material, and turn to the findings. The conclusions close the article.

\section{Setting the Context: Digital Media Innovation Among Legacy News Media}

The scholarly study of digital media innovation in the newsroom and beyond, among legacy news media, has become increasingly important since the fundaments which these build upon are in the midst of tremendous change. Information and communications technologies (ICTs), characterized as ubiquitous, integrated, immersive and pervasive (Deuze, 2009; 2011), have contributed to the shaping of a new media landscape where legacy news media has transformed significantly in terms of professional practices, platforms and business model as well as the function they serve for democracy. Contemporary network society marks an era characterized by continuous and rapid change where actors such as Google and Facebook, but also the social media magazine Flipboard and digital news content provider the Bleacher report $(B / R)$ are all engaging in innovation which leads to encroaching on the domain previously ruled by legacy news media. ICTs have changed how legacy news media produce and distribute their content and services, what content and services they offer, and how people use and interact with it. For some, the emerging news platforms complement the print and broadcasting, while for others these have had displacing effects (De Waal \& Schoenbach, 2010; Dimmick, Feaster \& Hoplamazian, 2011; Westlund \& Färdigh, 2011). Empirical research tracing changes in news consumption over four decades shows that older generations have largely maintained their use of legacy news media, while younger generations spend much more attention on the digital news platforms they have 
grown up with (Westlund \& Weibull, 2013). More recently, the tremendous uptake of mobile news has resulted in both displacing and complementary effects on the habits of using other news media (Westlund \& Färdigh, 2015).

Newsrooms across the newspaper industry have developed different types of measures with the aim of providing omnipresent access through websites, sites and applications for mobile devices and tablets, as well as by connecting to various social media providers. These measures - forming media product portfolios - are aimed at counterbalancing the losses of readership and revenues in print. Picard (2005) discusses how media product portfolios reduce newspapers risks and costs by entering new markets. Technology has become integral to the production and distribution of news. Continuous media innovation for digital and mobile platforms has become institutionalized into the textures of newspaper organizations and their newsrooms, thus creating these hybrids between print and digital (Raviola, 2010; Westlund, 2013).

Acknowledging the diverse and distinct agents within news media companies (Lewis \& Westlund, 2015; Westlund \& Lewis, 2014), literature suggests changes within the professional ideals, cultures and routines of media workers in legacy news media (Lewis, 2012; Westlund, 2011). There are tensions between the institutionalized print cultures vis-à-vis emerging forms of digital news production (Domingo, 2008; Spyridou, Matsiola, Veglis, Kalliris, \& Dimoulas, 2013; Westlund, 2011). More importantly, much research has been devoted to identify, describe and explain the fine yet contested tensions between "the creative autonomy of culture creators" on the one hand, and "the scientific management of commercial enterprises" on the other (Jenkins \& Deuze, 2008: 8). Research from previous decades has reported on different kinds of walls - visible as well as invisible - having been erected between editorial and market departments within news media companies (Franklin \& Murphy, 1991; Underwood, 1993; McManus, 1994). More recent academic studies have reported on "cultural clashes" (Compaine, 2006), and also duality management as a way to organize the cultures and interests of the journalists (e.g. the "words" or the "church") and the businesspeople (the "money") internally in the salient case of news media companies (Achtenhagen and Raviola, 2009; Westlund, 2012). Moreover, an industry report representative to the Nordic countries has shown that four out of ten newspaper managers claimed that it was important to "encourage understanding and cooperation between departments" (Stone, Nel \& Wilberg, 2010).

Importantly, it is not only journalists and businesspeople who are central agents within contemporary news organizations, but also different sorts of technologists. It appears to be salient that technological change has disrupted the formerly established walls between journalism and commerce, and that the rise of technologically oriented media work has introduced a dynamic shift in the role played by technologists. It is also clear that the technologists within (or beyond) the IT department are responsible for developing and maintaining digital media platforms as well as various technological infrastructures, applications and algorithms. The editorial department, on the other hand, produces and publishes 
the content, while the business department promotes content and services, generating profits from both business-to-consumer and business-to-business activities (Lewis \& Usher, 2013; Westlund, 2011). Qualitative case studies on media innovation for blogs (Nielsen, 2012) and mobile media (Westlund, 2012) have revealed various forms of ongoing negotiations and tensions between these three groups of media workers.

Importantly, other recent studies suggest that technologists seem to increasingly require taking part in the shaping of digital journalism (Parasie \& Dagiral, 2012; Gynnild, 2013), thus bringing computational thinking into newsrooms (Lewis \& Usher, 2013; Karlsen \& Stavelin. 2014). Importantly, the incorporation of IT expertise into televised news production, for instance, has resulted in clashes with traditional news production culture (Bennett \& Strange, 2012). The significance of technologists may vary with different companies, depending on their organizational cultures and size, which in turn relate to their resources (Wade \& Hulland, 2004) and dynamic capabilities (Zollo \& Winter, 2002). In the salient case of media innovations, an interview-focused case study with a Swedish newspaper reported how managers continuously sought to bring journalists, businesspeople and technologists together in diverse project groups and teams when working with digital developments. They shared ambitions towards achieving collaboration among these different social actors, attempting to erase former walls. While they seemingly made a major intra-organizational cultural transition - referred to as taking place in most other Swedish newspapers as well - they also repeatedly encountered difficulties since they were unfamiliar with working closely with each other (Westlund, 2011; 2012). Similarly, a U.K. based interview and document study by Doyle (2014) reports on work towards intra-organizational collaboration between journalists, businesspeople and technologists, concluding that media managers found this difficult to accomplish due to the supremacy of the journalists and the print journalism culture. Drawing upon communalities of experience among various newspapers, she concludes: "At a time of immense change and opportunity, a willingness to experiment, especially in relation to harnessing the benefits of two-way connectivity is vital and so too is the need to achieve close integration between IT, commercial and editorial functions" (Doyle, 2014: 17).

A growing number of qualitative studies suggest that more and more technologically trained professionals have entered newsrooms and the journalism community, shouldering an increasingly significant role in their digital media innovation. However, there are only a few quantitative studies focusing on intra-organizational perceptions of who takes part in innovation and the ways departmental members collaborate (Sylvie, 1996; Gade, 2008). Moreover, these studies only reveal patterns from the United States, studying only managers' and journalists' in newspapers, and thus exclude the role of technology and technologists. The bottom line is that research provides mixed findings on intraorganizational collaboration, revealing that cultural walls have had significance, yet providing indications of ambitions and efforts towards journalists, businesspeople and technologists working together more and more. 
Intra-organizational collaboration may vary by culture and structure, which brings us to the size of the media firm. The relationship between innovation and the size of media firms has given rise to much dispute in innovation literature. In times of change, large corporations have the economic strength to invest in innovation and develop new services, and can afford the risk of allocating resources to new areas. They have the power to influence market developments and take advantage of economies of scale and scope (Damanpour, 1992; Porter, 2008). However, being big is not only an advantage: it involves challenges for making innovative choices, especially if the innovation has a disruptive character (Christensen, 1997). Experience from the development of the Internet market does not give rise to clear-cut predictions about the impact of company size on innovation in the newspaper industry, but Krumsvik, Skogerbø \& Storsul (2013) found both size and media group ownership predicted innovation capacity in newspaper services for tablets.

Ultimately, intra-organizational shaping of digital media innovation marks an important area for further inquiry if we are to grasp the evolving future of journalism, and its interrelatedness to financial conditions, company size, media technologies and democracy. In particular, systematic and quantitative research across different media companies would fill a void in contemporary research literature.

\section{Problems of Organizational Change and the Adaptive Cycle in Newspapers}

Newspaper organizations are in some cases led by a publisher, who is ultimately responsible for both journalism and commerce, a model common in the United States. In other cases there are two leaders responsible for each of these areas, respectively, through duality management (Achtenhagen \& Raviola, 2009). This refers to organizations in which one leader is in charge of journalism and the editorial department (the editor-in-chief), and where another leader is responsible for commerce and the business department (the managing director or CEO). This organizing into silos has been pursued to grant journalism autonomy (Küng, 2007). The separation of the two has not only been common among newspapers, but is also a feature of many media companies that seek to balance the (scientific) management of commercial activities (aimed at developing customer- and business-oriented products) with the autonomy of culture creators (Jenkins \& Deuze, 2008; Deuze, 2010). In newspapers, the separation of the two has, not surprisingly, fostered tensions between the business side and the journalistic ideals and practices of the editorial side (Franklin \& Murphy, 1991; McManus, 1994; Underwood, 1993). Such organization has been described as silo-structured (van Weezel, 2009), involving both visible and invisible walls. Fagerling and Norbäck (2005) have argued that both mental and social boundaries exist between the editorial and business departments. Historically this has been visible from the structures and hierarchies in organizing the newspapers, but also in terms of allocating the editorial and business departments on different floors or even buildings (e.g. the Chicago Tribune or Göteborgs-Posten). The walls have been 
reproduced in everyday practices at newspapers, as media workers from the different departments have organized and carried out their daily work independently of each other.

However, those boundaries are now transforming with varying pace across different contexts. This influences intra-organizational work with digital media innovation. The adaptive cycle model for organizational innovation, developed by Miles and Snow (2003), creates a theoretical framework that has been widely used in studies of organizational change and innovation processes (Doty, Glick \& Huber, 1993; Hambrick, 2003). The adaptive cycle model was developed from a study of, among others, the publishing industry. Over the years it has proven to be a robust model for the analysis of a broad range of industries, including newspapers and broadcasting in Scandinavia and the United States (Krumsvik, 2006; 2010). Following this, its theoretical framework has been applied to the analysis in this article.

The adaptive cycle model has been vital for the development of what is known as the configurational view of strategy; this explains that there is not an infinite number of alternative routes towards the goal, but rather a handful of fundamental alternatives between which to choose. The configurational view stresses that organizations make developments in relation to both external and internal factors through an ongoing process. Miles and Snow (2003: 3) write that "most organizations engage in an ongoing process of evaluating their purposes, questioning, verifying, and redefining the manner in which they interact with their environments". The ways in which newspapers manage environmental change processes in the digital habitat, in other words, relates to their internal resources and processes. The adaptive cycle model focuses on three main problems: (1) the entrepreneurial problem (domain definition); (2) the engineering problem (technology); and (3) the administrative problem (structure, process and innovation). A process of adaptation is less likely to occur sequentially throughout the three problems in established organizations, and processes of change may be triggered within all three. However, in the studies conducted by Miles and Snow, it appears that the fastest and most efficient adaptations occur when the right administrative changes are made. They describe the adaptive cycle as a general psychology of organizational behavior, providing a means for conceptualizing the major elements of adaptation.

The leading aspect of the administrative problem is to select areas of future innovations, while the lagging aspect involves the rationalization of structures and processes. Traditional single product organizations tend to ignore developments outside of their domain (i.e. their product and the target market), making mostly incremental growth through product and service developments closely related to their existing domain. Newspapers have traditionally positioned themselves in the domain of providing printed newspapers to national, regional or local newspaper markets. It has constituted a narrow and relatively stable domain decade after decade, until the wider provisioning and uptake of digitally-based news in the mid-nineties. The engineering problem essentially involves how to manage the new production and distribution. Miles and Snow suggest that 
organizations will pursue efficiency, which may result in making investments in durable and cost-efficient technology.

Newspapers have strived to maintain control of their old domain by keeping competitors at bay. However, this has proven more difficult in the new domain, as barriers of entry for online and mobile publishing are significantly smaller. The entry into the digital habitat has clearly represented a major shift for legacy news media towards omnipresent cross-media news publishing. Newspapers have traditionally treated print as their main medium and domain definition, whereas other platforms have been treated as complementary. Nonetheless, in recent years digital platforms have also become primary domains to some newspapers (Westlund \& Färdigh, 2011). Most recently, some legacy news media outlets have developed strategies where mobile comes first, with examples including Aftonbladet, the largest newspaper, news site and mobile news publisher in Scandinavia. But the levels of media innovation vary, not least with the size of the newspaper, with many smaller newspapers having significantly different resources and also a different composition of their audiences and advertisers. The bottom line is that newspapers have become hybrids between old and new, and their previously established production processes and modes of distribution are continuously transforming.

\section{Study Rationale}

As the fastest and most efficient adaptations are expected to occur when the right administrative changes are made, this study aims to investigate the administrative problem, which is twofold. On the one hand, legacy news media are expected to strive for control and performance by engaging in careful planning. Organizations typically employ a functional structure with an extensive division of labor, in which a dominant coalition of powerful members manages their change processes. On the other hand, organizing such processes in order to maintain stability and efficiency does not necessarily translate into fostering innovation (Miles \& Snow, 2003). Newspapers have typically been organized to carry out the daily activities of newsrooms related to publishing and distributing a newspaper, while commanding less attention to innovation per se. This article suggests that routinized media production, such as with the salient case of journalism, does not qualify as media innovation. However, one needs to take notice that such creative work has been treated as innovation by many scholars (cf. Dogruel, 2014).

The organizing of digital media innovations may involve setting aside functional structures, mobilizing staff with different skills through projects and teams to achieve collaboration (Westlund, 2011), such as with teams for news reporting and decision-making (Coyle, 1998; Schierhorn, Endres \& Schierhorn, 2001), as well as fostering projects of media innovation guided by principles of reengineering. The administrative problem thus involves intra-organizational 
coordination of media professionals' efforts towards both routine work and media innovation.

Discussing the salient case of media firms, Gershon (2012) argues that crossfunctional teams make a basic tenet of strategies that aim to respond to major competitive threats. He discusses that such teams are comprised of members from different departments who have varying skillsets. This has also been seen in other contemporary studies of newspapers' innovation processes (Westlund, 2011). The administrative problem in the salient case of digital media innovation in newspapers presents important research inquiries regarding the actors involved. Consequently, the research design used in this article has drawn valuable inferences from previous research on the perceptions among (editorial) managers on influence and collaboration (Gade, 2008), as well as research on their diverging interests in digital media innovation (Westlund, 2011).

Therefore, this article aims to study newspaper executives' perceptions of the interest and collaboration in digital media innovation among distinct actors within their newspaper. Such actors include all staff in the editorial, business and IT departments (e.g. departments encompassing staff with computational skills), as well as the owners, users, and industry associations. However, difficulties arise when measuring the interest and collaboration among these actors. This article does not study interest and collaboration per se, but rather focuses on editorial and business executives' perceptions of these issues (see method section for further discussion). Ultimately the article posits two research questions, which are both introduced next. Each of these research questions will be empirically scrutinized for 2011 and 2013, tracing possible changes over time. Moreover, following the discussion on previous research findings, each of the research questions will also control for significant differences depending on newspaper size. The bottom line is that these cross-sectional surveys with journalists, businesspeople and technologists make a unique contribution to how diverse intra-organizational agents potentially collaborate and shape contemporary media innovations.

\section{Perceptions of the Interest in Digital Media Innovation}

The administrative problem relates to media workers' interest in digital media innovation and organizational change in general, as journalists have often expressed resistance to organizational change (Paterson \& Domingo, 2008; Deuze, 2010). For instance, Ryfe (2009a; 2009b) explains that changes to journalistic practice have sometimes inferred change to their professional identity. This is one of the reasons why journalists have sought to keep changes at bay. Deuze (2008) adds that journalists have learned to be skeptical towards organizational changes, since these have been associated with negative aspects such as lay-offs and decreases in resources.

Perceptions of interest among these different professional groups are taken as an indicator of their willingness to participate in, and have influence on, their company's digital media innovation. As discussed above, there are intra- 
organizational tensions in news media organizations. Research suggests that these tensions relate to differences in interests and values among editorial vis-à-vis business departments (Weaver, Beam, Brownless, Voakes \& Wilhoit, 2007). Available research encompassing media managers and media workers from the editorial, business and IT departments suggests that their interest in digital media innovation varies (Westlund, 2011; Nielsen, 2012). Besides these few qualitative studies, empirical research is scarce: thus, little is known about the frequency with which media workers from different departments take a strong or limited interest in digital media innovation. Consequently, this article will utilize a quantitative survey method in order to analyze the first research question:

RQ1: Do newspaper executives perceive that there is diverging interest in digital media innovation across the editorial, business and IT departments of their organization?

\section{Perceptions of Organizational Collaboration}

The administrative problem of a newspaper organization relates to if, and if so, then how, different departmental members collaborate in media work and innovation. Research suggests that former boundaries limiting collaboration has started to dissolve in recent decades (Deuze, 2010). Gade (2008) discusses that organizational integration takes place as departments that have historically been autonomous now engage in collaboration. Obviously, there have been variations across the globe in terms of the level of collaboration between departments within news media organizations. In the United States, these walls had already started to erode in the 1970s (Merritt, 2005), while such change did not escalate until the start of the twenty-first century in Scandinavia (Westlund, 2011). Newspapers increasingly recognize collaboration among different departments as important to their strategy (Campbell, 2002; Gade \& Raviola, 2009), and journalists have acknowledged this as a possible option (Verweij, 2009) although they are generally cautious about relinquishing their professional control (Lewis, 2012). Collaboration has become common not only within but also between newspapers, with regards to innovation for journalism, as well as business and technology. This is salient from initiatives such as Learning Newsrooms, Newspaper Next, and the World Association of Newspapers (WAN-IFRA).

As media workers in newspapers have engaged in digital media innovation, they have explored new terrains in which new boundaries between the departments have been explored and defined. With increasingly difficult economic conditions (van Weezel, 2008), and ambitions for facilitating sustainable innovation processes (Gade \& Raviola, 2009), more collaboration is taking place (Nygren \& Zuiderveld, 2011; Westlund, 2011).

Ultimately, fostering intra-organizational collaboration is a way to manage the administrative problem. Research has shown differences regarding how 
representatives from the different departments perceive their collaboration. For instance, Sylvie (1996) reported that editors perceived inter-departmental collaboration as more important than the managers of specific business departments did. However, to our best knowledge, there are no quantitative studies encompassing newspaper executives' perceptions on how departmental members collaborate amid the rise of digital media innovation. Our second research question thus asks:

RQ2: Amid digital media innovation, and also the interest in such activities among departments, do newspaper executives' perceive that the collaboration between members of editorial, business and IT departments has increased?

\section{Method and Materials}

The study has been conducted in Norway, a Scandinavian country with a democratic-corporatist media system where newspapers and digital media occupy strong positions in terms of reach and usage (Hallin \& Mancini, 2004; Krumsvik 2013; Westlund \& Färdigh, 2011). The position of the press has historically been stronger in Scandinavia compared to the United States and elsewhere in the developed world (except for Japan and Switzerland). Nonetheless, newspapers in all of these countries have faced relatively similar challenges to their conditions for running a journalism business (Krumsvik et al. 2013). While the focus here is on the perceptions of Norwegian newspaper executives - journalists, businesspeople and technologists - the results presented here nonetheless hold wider significance for one's understanding of digital media innovation in newspaper organizations. More generally, the article may inform the perceptions among newspaper executives in sophisticated media markets where print is in decline and digital media is on the rise.

The empirical analysis draws upon two surveys of Norwegian newspaper executives conducted in April 2011 and April 2013. A total of 229 (2011) and 212 (2013) chief executives (Editor-in-Chief, Managing Director, and Publisher) in print papers responded to twenty-eight survey questions. Invitations were sent by e-mail to addresses provided by the Norwegian Media Businesses' Association (MBL) and the National Association of Local Newspapers (LLA). The survey was conducted on the web-based research service QuestBack. Respondents were not sampled as all member newspapers of these two associations were included, and non-response was interpreted as negative selfselection. The response rate was 59 percent (2011) and 60 percent (2013) after three rounds of email reminders. Surveys using the same methodological approach were conducted in 2005, 2007 and 2009 with similar response rates. Comparison of the different datasets shows no indications that the non-responses followed a different pattern in the 2011 and 2013 surveys. There is, however, a 
general tendency in these surveys of a lower response rate among Managing Directors. In the 2011 survey, 105 (46\%) respondents were Editors-in-Chief, 30 (13\%) Publishers and 68 (30\%) Managing Directors, while 24 (10\%) chose not to answer (these have been excluded from the analyses). Organizations do not have a register of management models in member newspapers; however, the dual management model of an Editor-in-Chief (EiC) and a Managing Director (MD) is the standard model in Norway. The EiC is then responsible for the editorial department and the MD for sales and marketing, with both reporting to the board of directors as joint chief executives. Hence, if the response rate was similar, the number of respondents from these two groups should be similar. At some newspapers the same person fills both roles, functioning as Publisher, according to this media system.

The surveys have focused on the perceptions of executives, the people responsible for developing strategy for their respective newspaper. RQ1 and RQ2 have been measured utilizing statements on their perceptions on intraorganizational interest and collaboration, respectively. Each research question has been operationalized into how they assess the role of key actors in their media organization, namely the different departments involved in digital media innovations. An alpha level of .05 applies to all statistical tests used (T-test, ANOVA and linear regression). Significant findings from this this study may be researched further using other methodological approaches.

\section{Findings}

This section presents findings of the executives' perception of the interest media workers from the editorial, business and IT departments have in digital media innovation (RQ1). It analyzes whether newspaper executives' perceive that specific forms of intra-organizational collaboration have increased, in light of their digital media innovation work and also the perceived interest in such activities among departments (RQ2).

\section{Perceptions of the Interest in Digital Media Innovation (RQ1)}

The perceived interest for working with digital media has not increased significantly from 2011 (Table 1a) to 2013 (Table 1b). The average score is between 4.27 and 4.77 on a 1-6 scale, which translates into actors generally having relatively modest interest in media innovation. Thus, the average media executives' view is that their organization lacks a pronounced interest in the innovation and development of new and digital media. This may constitute an administrative problem from the perspective of innovation and change (Miles \& Snow, 2003). However, in both surveys the IT department received the highest 


\begin{tabular}{lccccc} 
& $N$ & Mean & $\begin{array}{c}\text { Std. } \\
\text { deviation }\end{array}$ & $\begin{array}{c}\text { Editor } \\
\text { (Mean) }\end{array}$ & $\begin{array}{c}\text { Managing } \\
\text { Director } \\
\text { (Mean) }\end{array}$ \\
\hline Editorial & 202 & 4.32 & 1.097 & 4.36 & 4.35 \\
Business & 202 & 4.27 & 1.124 & $4.10^{*}$ & $4.65^{*}$ \\
$I T$ & 195 & 4.63 & 1.255 & $4,41^{*}$ & $4.91^{*}$
\end{tabular}

Table 1a. Perceptions of departmental interest in digital media innovation (2011). Question in survey: How would you assess the general interest/willingness to participate in the development of new media in these groups? $1=$ low degree $6=$ high degree. $(*)$ The mean difference between executive groups was significant at the .05 level.

\begin{tabular}{lccccc} 
& $N$ & Mean & $\begin{array}{c}\text { Std. } \\
\text { deviation }\end{array}$ & $\begin{array}{c}\text { Editor } \\
\text { (Mean) }\end{array}$ & $\begin{array}{c}\text { Managing } \\
\text { Director } \\
\text { (Mean) }\end{array}$ \\
\hline Editorial & 189 & 4.47 & 1.01 & 4.63 & 4.28 \\
Business & 189 & 4.40 & 1.10 & $4.25^{*}$ & $4.74^{*}$ \\
$I T$ & 181 & 4.77 & 1.09 & 4.66 & 5.05
\end{tabular}

Table 1b. Perceptions of departmental interest in digital media innovation (2013). Question in survey: How would you assess the general interest/willingness to participate in the development of new media in these groups? $1=$ low degree $6=$ high degree. $\left.{ }^{*}\right)$ The mean difference between groups of executives was significant at the .05 level.

score, significantly higher than the business department in 2011, and higher than both business and editorial departments in 2013.

The results in Tables $1 \mathrm{a}$ and $1 \mathrm{~b}$ also show differences and similarities depending on the executive role. It is evident that the two main groups of executives (Editor-in-Chief, Managing Director) do not have significantly different views on the editorial department's interest in developing digital media. However, executives with editorial responsibilities (Editors 2011, 2013; Publishers 2011 not included in Table 1) have a significantly different view of the business department as compared with those of the Managing Directors, who essentially consider their business department to be more interested in digital media innovation than the perception of others. Furthermore, the Managing Directors perceived the IT department as being significantly more interested in digital media innovation $(M=4.91, S D=1.02)$ than Editors-in-Chief $(M=4.41$, $S D=1.38)$ in 2011 . The difference was however not statistically significant in 2013.

Although not conveyed in the tables, the analysis has also explored differences in perceptions of the interest in digital media innovation depending on the newspaper's size. The analysis revealed significant differences in 2011, but not for 2013, as they relate to their varying resources and motivations for media 
innovation. In the 2011 survey, the editorial departments of large newspapers (circulation over $40,000, M=5.08$ ) were perceived to be significantly more interested than the editorial departments in mid-sized newspapers (circulation of 10-40,000, $M=4.19$ ). Moreover, the perceived interest among business departments in the smallest newspapers (circulation under 5,000, $M=4.01$ ) was significantly smaller compared to the largest newspapers (circulation over 40,000, $M=4.92$ ). This pattern is particularly pronounced as this accounts for the differences in the size of newspapers and the perceived interest of the IT department. The results show that the perceived interest of the IT department at the smallest newspapers (circulation under 5,000, $M=4.18$ ) is significantly lower compared to both the mid-sized $(10-40,000, M=5.85)$ and largest newspapers (over 40,000, mean $=5.54$ ).

\section{Perceptions of Organizational Collaboration (RQ2)}

The research literature discussed earlier provides mixed findings on how intraorganizational collaboration takes place; again, much research has revealed different kinds of clashes and tensions (Jenkins \& Deuze, 2008; Underwood, 1993), but also that these tensions are easing in the processes of different departmental members engaging more and more in collaboration (Stone et al. 2010; Westlund, 2011; 2012). Throughout the course of digital media innovation, new territories have been explored, understood, and jointly defined. The literature seems to suggest that increasing intra-organizational collaboration results from digital media innovation.

In this part of the findings, we are first presenting perceptions of whether intra-organizational collaboration has increased because of digital media innovation work (Tables $2 \mathrm{a}$ and $2 \mathrm{~b}$ ), then perceptions of departmental interest in digital media innovation as predictors for perceptions of intra-organizational collaboration (Tables $3 \mathrm{a}$ and $3 \mathrm{~b}$ ).

Tables $2 \mathrm{a}$ and $2 \mathrm{~b}$ show that the various explorations of digital media are generally not perceived to have fostered increased collaboration between the two sides of duality management. The results reveal no significant difference overall in the perception of collaboration between the three departments. There are, however, some differences in perceptions between the groups of media executives in 2011 that are worth considering. The Editors-in-Chief pose a significantly lower figure $(M=2.79, S D=1.39)$ for their perception of collaboration between the editorial and business departments than the Managing Directors $(M=3.33, S D=1.52)$. On the other hand, one should consider that the managing directors express a significantly higher level of collaboration between the business and IT departments than the Editors-in-Chief do. Following this, commercial leaders seemed to make a more favorable interpretation of collaboration tendencies in 2011. In 2013 there was no statistical significant difference between the groups of executives. However, means for various sizes of 
Table 2a. Perceptions of whether intra-organizational collaboration has increased because of digital media innovation work (2011). Question in survey: To what extent has the collaboration between the following groups increased as a result of working with new media? $1=$ to a small extent $6=$ to a large extent. $(*)$ The mean difference is significant at the .05 level.

\begin{tabular}{lccccc} 
& $N$ & Mean & $\begin{array}{c}\text { Std. } \\
\text { deviation }\end{array}$ & $\begin{array}{c}\text { Editor-in- } \\
\text { Chief } \\
\text { (Mean) }\end{array}$ & $\begin{array}{c}\text { Managing } \\
\text { Director. } \\
\text { (Mean) }\end{array}$ \\
\hline Editorial vs. Business & 199 & 2.94 & 1.44 & $2.79^{*}$ & $3.33^{*}$ \\
Editorial vs. IT & 194 & 3.31 & 1.41 & 3.19 & 3.42 \\
IT vs. Business & 194 & 3.18 & 1.39 & $2.96^{*}$ & $3.58^{*}$
\end{tabular}

Table 2b. Perceptions of whether intra-organizational collaboration has increased because of digital media innovation work (2013). Question in survey: To what extent has the collaboration between the following groups increased as a result of working with new media? $1=$ to a small extent $6=$ to a large extent. The mean difference is not significant between groups

\begin{tabular}{cccccc} 
& $N$ & Mean & $\begin{array}{c}\text { Std. } \\
\text { deviation }\end{array}$ & $\begin{array}{c}\text { Editor-in- } \\
\text { Chief } \\
\text { (Mean) }\end{array}$ & $\begin{array}{c}\text { Managing } \\
\text { Director. } \\
\text { (Mean) }\end{array}$ \\
\hline Editorial vs. Business & 186 & 3.05 & 1.41 & 3.12 & 3.02 \\
Editorial vs. IT & 180 & 3.20 & 1.41 & 3.34 & 3.15 \\
IT vs. Business & 179 & 3.17 & 1.36 & 3.27 & 3.22
\end{tabular}

newspapers was significantly different for all three relationships in 2013: Editorial vs. Business, $X^{2}(3, N=185)=18.207, p=.000$; Editorial vs. IT, $X^{2}(3$, $N=179)=13.421, p=.000$; Business vs. IT: $X^{2}(3, N=178)=6.676, p=.000$. The same differences were significant in 2011: Editorial vs. Business, $X^{2}(3, N=$ $209)=18.899, p=.000$; Editorial vs. IT, $X^{2}(3, N=204)=14.902, p=.000$; Business vs. IT: $X^{2}(3, N=204)=16.538, p=.000$. Larger newspapers thus had higher scores on intra-organizational collaboration.

The findings presented in Tables $3 \mathrm{a}$ and $3 \mathrm{~b}$ show that perceptions of the IT department's interest in media innovation constitutes a significant predictor for perception on intra-organizational collaboration. In 2011 this was the most important predictor for all three categories, and also for the perception of collaboration between the editorial and business departments (Table 3a).

The findings from these linear regression analyses strengthen the indication presented in Tables $1 \mathrm{a}$ and $1 \mathrm{~b}$, thus indicating the critical role of the IT department in digital media innovation. The IT department is not only regarded as the most enthusiastic part of the organization, but also their engagement holds the key to perceptions of cross-functional collaboration. In contrast, the findings might indicate the editorial department plays a distinctive and less critical role. 
Table 3a. Perceptions of departmental interest in digital media innovation as predictors for perceptions of intra-organizational collaboration (2011). ${ }^{\mathrm{a}} \mathrm{R}^{2}=.112 \quad(p=.000)$; ${ }^{\mathrm{b}} \mathrm{R}^{2}=.252(\mathrm{p}=.000) ;{ }^{\mathrm{c}} \mathrm{R}^{2}=.271(\mathrm{p}=.000)$.

\begin{tabular}{lllll} 
Dependent variable & Predictors & $B$ & SE B & $\beta$ \\
\hline Editorial vs. Business $^{a}$ & IT & .233 & .082 & .206 \\
& Business & .250 & .094 & .194 \\
& & & & \\
Editorial vs. IT $^{b}$ & IT & .518 & .070 & .465 \\
& Editorial & .161 & .081 & .125 \\
IT vs. Business & & & & \\
& IT & .500 & .073 & .454 \\
& Business & .175 & 0.86 & .135
\end{tabular}

Table $3 b$. Perceptions of departmental interest in digital media innovation as predictors for perceptions of intra-organizational collaboration (2013). ${ }^{\mathrm{a}} \mathrm{R}^{2}=.065 \quad(p=.001)$; ${ }^{\mathrm{b}} \mathrm{R}^{2}=.121(\mathrm{p}=.000) ;{ }^{\mathrm{c}} \mathrm{R}^{2}=.089(\mathrm{p}=.000)$.

\begin{tabular}{lllll} 
Dependent variable $^{a}$ & Predictors & $B$ & SE B & $\beta$ \\
\hline Editorial vs. Business $^{a}$ & Business & .335 & .096 & .255 \\
Editorial vs. IT $^{b}$ & & & & \\
& EdT & .291 & .099 & .220 \\
& & .308 & .107 & .215 \\
EdT vs. Business $^{c}$ & IT & .383 & .093 & .299
\end{tabular}

\section{Discussion}

The article has addressed the perceived intra-organizational interplay for digital media innovation in newspapers from the view of the top executives. The two cross-sectional surveys have been brought together into a unique quantitative study, focusing on top executives' perceptions regarding the interest in and collaboration among and between actors in different departments involved in newspapers media innovation specifically, and their administrative problem of adaptation more generally.

Our first research question showed that newspaper executives perceive their employees as having a modest interest in digital media innovation. The IT department was perceived as being the most interested, especially in the views of the Managing Directors. Ultimately, newspapers may find that they have an administrative problem in terms of their staff coming up relatively short in their interest in media innovation. This goes in concert with previous research 
documenting journalists as disinterested in change and innovation (c.f. Lewis, 2012; Ryfe 2009a; Ryfe 2009b).

Secondly, we investigated perceptions focusing on whether collaboration between members of editorial, business and IT departments has increased. The structure of dual management is unchanged as the preferred management model of legacy news media in Norway, and the intra-organizational collaboration appears to have changed only to a small degree. The media workers involved in production (editorial staff of the newsroom) as well as marketing, sales and business development (business department) are perceived to be significantly less interested in digital innovation work than their colleagues in the IT department. Hence, the newspapers might be limited in their ability to accomplish the effective administrative changes (i.e. structure, process, and innovation) outlined in the adaptive cycle model.

While the former single purpose organizations of newspapers have developed into media houses with a portfolio of products and services, the basic structure of dual management has been unchanged, deeply rooted in the Norwegian industry norms, requiring a separation of the church and the state in the news media (Storsul \& Krumsvik, 2013, p. 19). Contrary to expectations in the literature, the present study does not reveal a substantial increase in perceived collaboration between the two sides of duality management, as suggested by American and Scandinavian studies (Deuze, 2010). While the Managing Directors and Editorsin-Chief had different views on the degree of change in 2011, the 2013 survey revealed consensus on the issues. Amid substantial digital media innovation and also the interest in such activities among departments, a multivariate analysis revealed the perceived interest of change in the IT department to be a key predictor for perceived change in intra-organizational collaboration.

In a situation where the entrepreneurial problem (domain definition) of the adaptive cycle in newspapers is increasingly defined by owners (Krumsvik \& Westlund, 2014), and we find the ability to execute administrative changes to be limited, so the internal driver for adaptation might be the department in charge of the engineering problem (technology). We find a significant relationship between the size of newspapers and their perceived inter-organizational collaboration level, while larger newspapers also have more R\&D capacity in the IT departments, or similar centralized functions in media groups (Krumsvik et al. 2013). Following this, a situation emerges where the engineering problem potentially becomes the most important internal key to change the processes in legacy news organizations. On the other hand, it is also worth noting that the perceived willingness of change in the newsroom was not found to be the most important predictor for intra-organizational collaboration. The autonomy of the newsroom, with the professional logic subscribed to by journalists (Lewis, 2012), alongside the silo organization models, have much importance. These conditions relate to fundamental questions for both newspaper organizations and the academic community, concerning how information and communication technologies can be used for repurposing vis-à-vis customization of content and 
services for the increasing number of news platforms. The organizational configuration of a traditional news organization might not provide a feasible framework for customization.

To summarize, this study casts light on the psychology at work in the behavior of legacy news organizations. The article demonstrates the importance of studying the perspectives of various internal actors (i.e. business, editorial, and IT) for the shaping of media innovations. The findings demonstrate that the various technologists at the IT department - rather than the editorial newsroom or the business department - are perceived to be central for triggering adaptations to altering conditions for production and distribution of news. These findings, in the context of external pressure on legacy news media due to a transforming and increasingly challenging mediascape, indicate a situation where the management might choose to focus on the lagging aspect of the administrative problem (rationalization) based on technological determinism, rather than the leading aspect (innovation) based on the strategic choices of future domains. This is likely to have a negative effect on the efficiency of change in newspapers.

While this article articulates the perceptions of Editors-in-Chief and Managing Directors, further research could investigate these issues from other perspectives as well, using a wider variety of methodological approaches, including in-depth interviews and ethnographic observations in order to gain a deeper understanding of how distinct groups of social actors in legacy news media participate and collaborate in the shaping of media innovations and the future of journalism.

\section{References}

Achtenhagen, L. \& Raviola, E. (2009). Balancing tensions during convergence:

Duality management in a newspaper company. International Journal on Media Management, 11(1), 32-41. doi: 10.1080/14241270802518505

Anderson, C. W., Bell, E. \& Shirky, C. (2012). Post-industrial journalism:

Adapting to the present. New York: Tow Center for Digital Journalism,

Columbia University. Retrieved from http://towcenter.org/research/postindustrial-journalism/

Baumann, S. (2013). Adapting to the brave new world: Innovative organisational strategies for media companies. In T. Storsul \& A.H. Krumsvik (eds.), Media Innovation. A Multidisciplinary Study of Change (pp. 77-92). Göteborg: Nordicom.

Bennett, J. \& Strange, N. (2012). Linear legacies: Managing the multiplatform production process, in D. Kompare, D. Johnson \& A. Santo (eds.), Intermediaries: Cultures of management/management of culture. New York: NYU Press. 
Bleyen, V., Lindmark, S., Ranaivoson, H. \& Ballon, P. (2014). A typology of media innovations: Insights from an exploratory study. The Journal of Media Innovations, 1(1), 28-51. doi: 10.5617/jmi.v1i1.800

Bruns, A. (2014). Media innovations, user innovations, societal innovations. The Journal of Media Innovations, 1(1), 13-27.

Campbell, D. (2002). Help wanted: Newspapers are finding it increasingly difficult to fill top-level editing positions. American Journalism Review, November 2002, 56-61.

Christensen, C. M. (1997). The innovator's dilemma: when new technologies cause great firms to fail. Boston, Mass: Harvard Business School Press.

Compaine, B. (2006). Handbook of media management and economics. Journal of Media Economics, 19(4), 279-285. doi: 10.1207/s15327736me1904_4

Coyle, J. S. (1998). Now, the editor as marketer. Columbia Journalism Review, July/August 1998, 37-41.

Damanpour, F. (1992). Organizational size and innovation. Organization Studies, 13, 375-402. doi: 10.1177/017084069201300304

Deuze, M. (2008). The changing context of news work: Liquid journalism for a monitorial citizenry. International Journal of Communication, 2, 848-865.

Deuze, M. (2009). Media industries, work and life, European Journal of Communication, 24(4), 1-14.

Deuze, M. (2010). Managing Media Work. London: Sage Publications.

Deuze, M. (2011). Media life, Media Culture \& Society, 33(1), 137-148.

De Waal, E. \& Schoenbach, K. (2010). News sites' position in the mediascape: Uses, evaluations and media displacement effects over time. New Media \& Society, 12(3), 477-496.

Dimmick, J. W., Feaster, J. C. \& Hoplamazian, G. J. (2011). News in the interstices: The niches of mobile media in space and time. New Media \& Society, 13(1), 23-39.

Dogruel, L. (2014). What is so special about media innovations? A characterization of the field. The Journal of Media Innovations, 1(1), 28-51.

Domingo, D. (2008). Interactivity in the daily routines of online newsrooms: dealing with an uncomfortable myth. Journal of Computer-Mediated Communication, 13(3), 680-704.

Doyle, G. (2014). Re-invention and survival: newspapers in the era of digital multiplatform delivery. Journal of Media Business Studies, 10 (4), 1-20.

Doty, H. D., Glick, W. H. \& Huber, G. P. (1993). Fit equifinality and organisational effectiveness: A test of two configurational theories. Academy of Management Journal, 36(6), 1196-1250.

Fagerling, M. \& Norbäck, M. (2005). Newsroom identities: Group configurations and transforming boundaries during the introduction of a web edition. Intervention Research, 1(2), 191-207.

Franklin, B. \& Murphy, D. (1991). What news? The market, politics and the local press, London: Routledge. 
Gade, P. J. (2008). Journalism guardians in a time of great change: Newspaper editors' perceived influence in integrated news organizations. Journalism \& Mass Communication Quarterly, 85(2), 371-392.

Gade, P. J. \& Raviola, E. (2009). Integration of news and news integration: A structural perspective on new media changes. Journal of Media Business Studies, 6(1), 87-111.

Gershon, R. A. (2012). Business process innovation and the intelligent network, In Z. Vukanovic \& P. Faustino (Eds.), managing media economy, media content and technology in the age of digital convergence. Montenegro: Media XXI.

Gynnild, A. (2013). Journalism innovation leads to innovation journalism: The impact of computational exploration on changing mindsets. Journalism. doi: $10.1177 / 1464884913486393$

Hallin, D. C. \& Mancini, P. (2004). Comparing media systems. Cambridge: Cambridge University Press.

Hambrick, D. C. (2003). Foreword to the classic edition, In R. E. Miles \& C. C. Snow (Eds.), Organizational strategy, structure, and process (pp. 1-2). California: Stanford University Press.

Jenkins, H. \& Deuze, M. (2008). Editorial: Convergence culture. Convergence, 14(5), 5-12.

Karlsen, J. \& Stavelin, E. (2014). Computational journalism in Norwegian newsrooms. Journalism Practice, 8(1), 34-48. $10.1080 / 17512786.2013 .813190$

Krumsvik, A.H. (2006). The strategic role of online newspapers. Nordicom Review, 27(2), 285-297.

Krumsvik, A. H. (2010). Strategy and structure for online news production: Case studies of CNN and NRK. In M.M. Allen, J. Hunsinger \& L. Klastrup, International handbook of internet research (pp. 325-340), Berlin: Springer, 2010.

Krumsvik, A. H. (2013). Freedom of expression and the professionalization of journalism. In Freedom of expression revisited: Citizenship and journalism in the digital era. U. Carlsson (Ed.) (pp. 61-72), Gothenburg: Nordicom.

Krumsvik, A. H., Skogerbø, E. \& Storsul, T. (2013). Size, ownership and innovation in newspapers. In T. Storsul \& A. H. Krumsvik (Eds.), Media innovations: A multidisciplinary study of change (pp. 93-109). Gothenburg: Nordicom.

Krumsvik, A. H. \& Westlund, O. (2014). Hvem tar initiativ til innovasjonsprosesser i nyhetsmediene? En historisk gjennomgang. In L. Morlandstø \& A. H. Krumsvik (Eds.). Innovasjon og verdiskaping i lokale medier (pp. 33-49). Oslo: Cappelen Damm Akademisk.

Küng, L. (2007). Does media management matter? Establishing the scope, rationale and future research agenda for the discipline. Journal of Media Business Studies, 4(1), 21-39. 
Lewis, S. C. (2012). The tension between professional control and open participation: Journalism and its boundaries. Information, Communication \& Society, 15(6), 836-866. doi:10.1080/1369118X.2012.674150

Lewis, S. C. \& Westlund, O. (2015). Actors, actants, audiences, and activities in cross-media news work. Digital Journalism, 3(1). doi:

10.1080/21670811.2014.927986

Lewis, S. C. \& Usher, N. (2013). Open source and journalism: Toward new frameworks for imagining news innovation. Media, Culture \& Society, 35(5), 602-619. doi:10.1177/0163443713485494

McManus, J. H. (1994). Market-driven journalism: Let the citizen beware? California: Sage Publications.

Merritt, D. (2005). Knightfall: Knight Ridder and how the erosion of newspaper journalism is putting democracy at risk. New York: AMACOM.

Mierzjewska, B. I. \& Hollifield, A. C. (2006). Theoretical approaches in media management research. In A.B. Albarran, S. Chan-Olmsted \& M. O. Wirth (Eds.), Mahwah, Handbook of media management and economics (pp. 37-66), NJ: Lawrence Erlbaum Associates, Inc.

Miles, R. E. \& Snow, C. C. (2003). Organizational strategy, structure, and process: Stanford business classics. Stanford: Stanford University Press.

Nielsen, R. K. (2012). How newspapers began to blog: Recognizing the role of technologists in old media organizations' development of new media technologies. Information, Communication \& Society, 15(6), 959-978. doi: 10.1080/1369118X.2012.694898

Nygren, G. \& Zuiderveld, M. (2011). En himla många kanaler: Flerkanalpublicering $i$ svenska mediehus 2010 [A bunch of channels: Multichannel publishing in Swedish media houses 2010], Gothenburg: Nordicom.

Parasie, S. \& Dagiral, E. (2013). Data-driven journalism and the public good: "Computer-assisted-reporters" and "programmer-journalists" in Chicago. New Media \& Society, 15(6), 853-871. doi:10.1080/1369118X.2012.694898

Pavlik, J. V. (2013). Trends in new media research: A critical review of recent scholarship. Sociology Compass, 7(1), 1-12. doi:10.1177/1461444812463345

Paterson, C. A. \& Domingo, D. (2008). Making online news: The ethnography of new media production, New York: Peter Lang.

Picard, R. G. (2005). Media product portfolios: Issues in management of multiple products and services. NJ: Lawrence Erlbaum Associates.

Picard, R. G. (2014). Twilight or new dawn of journalism? Journalism Studies, doi: 10.1080/1461670X.2014.895530

Porter, M. E. (2008). On competition, updated and expanded edition. Boston: Harvard Business School Press.

Raviola, E. (2010). Paper meets web - how the institution of news production works on paper and online. JIBS Dissertation Series No. 065, Jönköping International Business School, Jönköping, Sweden. 
Ryfe, D. M. (2009a). Broader and deeper: A study of newsroom culture in a time of change. Journalism, 10(2), 197-216. doi: 10.1177/1464884908100601

Ryfe, D. M. (2009b). Structure, agency, and change in an American newsroom. Journalism, 10(5), 665-683. doi: 10.1177/1464884909106538

Schierhorn, A. B, Endres, F. \& Schierhorn, C. (2001). Newsroom teams enjoy rapid growth in the 1990s. Newspaper Research Journal, 22(3), 2-15.

Snow C. C., Miles, R. E. \& Miles, G. (2005). A configurational approach to the integration of strategy and organization research. Strategic Organization, 3(4), 431-439. doi: 10.1177/1476127005057965

Spyridou, L-P., Matsiola, M., Veglis, A., Kalliris, G. \& Dimoulas, C. (2013) Journalism in a state of flux: Journalists as agents of technology innovation and emerging news practices. International Communication Gazette, 75(1), 76-98.

Stone M., Nel, F. \& Wilberg, E. (2010). World news future and change study 2010. Paris, France: World Association of Newspapers and News Publishers (WAN-IFRA).

Storsul, T. \& Krumsvik, A. H. (2013). What is media innovations? In T. Storsul \& A. H. Krumsvik (Eds.), Media innovations: A multidisciplinary study of change (pp. 13-26). Gothenburg: Nordicom.

Sylvie, G. (1996). Departmental influences on interdepartmental cooperation at daily newspapers. Journalism \& Mass Communication Quarterly, 73(1), 230241. doi: $10.1177 / 107769909607300120$

Sylvie, G. \& Weiss, A. S. (2012). Putting the management into innovation \& media management studies: A meta-analysis. International Journal on Media Management, 14(3), 183-206. doi: 10.1080/14241277.2011.633584

Underwood, D. (1993). When MBAs rule the newsroom: How the marketers and managers are reshaping today's media. New York: Columbia University Press.

Van Weezel, A. (2009). Organizational changes in newspaper firms and their relation to performance. International Journal on Media Management, 11(3), 144-152. doi: 10.1080/14241270903278868

Verweij, P. (2009). Making convergence work in the newsroom: A case study of convergence of print, radio, television and online newsrooms at the African media matrix in South Africa during the National Arts Festival. Convergence, 15(1), 75-87. doi: 10.1177/1354856508097020

Wade, M. \& Hulland, J. (2004). Review: The resource-based view and information systems research: Review, extension, and suggestions for future research. MIS Quarterly, 28(1), 107-142.

Weaver, D. H. Beam, R. A. Brownlee, B. L. Voakes, P. S. \& Wilhoit, C. G. (2007). The American journalist in the 21st Century: U.S. news people at the dawn of a new millennium. Mahwah, NJ: Lawrence Erlbaum. Westlund, O. (2011). Cross-media news work: Sensemaking of the mobile media (r)evolution. Gothenburg: JMG Book Series no. 64, University of Gothenburg. doi: https://gupea.ub.gu.se/handle/2077/28118 
Westlund, O. (2012). Producer-Centric Vs. Participation-Centric: On the Shaping of Mobile Media. Northern Lights, 10(1), 107-121. doi: 10.1386/nl.10.107_1

Westlund, O. (2013). Mobile news: a review and model of journalism in an age of mobile media. Digital Journalism, 1(1), 6-26. doi:10.1080/21670811.2012.74027

Westlund, O. \& Färdigh, M. A. (2011). Displacing and complementing effects of news sites on newspapers 1998-2009. International Journal on Media Management, 13(3), 177-194. doi: 10.1080/14241277.2011.595020

Westlund, O. \& Färdigh, M.A. (Forthcoming). Accessing the News in an Age of Mobile Media, Mobile Media \& Communication, 3(1).

Westlund, O. \& Lewis, S.C. (2014). Agents of Media Innovation: Actors, Actants, and Audiences, The Journal of Media Innovations, 1(2), 10-35.

Westlund, O. \& Weibull, L. (2013). Generation, life course and news media use in Sweden 1986-2011. Northern Lights, 11(1), 147-173. 10.1386/nl.11.1.147_1

Wirth, M. O. (2006). Issues in media convergence, Handbook of media management and economics, In A. B. Albarran, S. Chan-Olmsted \& M. O. Wirth (Eds.), Mahwah, Handbook of media management and economics (pp. 445-462). NJ: Lawrence Erlbaum Associates, Inc.

Zollo, M. \& Winter, S. G. (2002). Deliberate learning and the evolution of dynamic capabilities. Organization Science, 13(3), 339-351. 